\title{
Iklan Layanan Masyarakat Dalam Mengurangi Kecelakaan Lalu Lintas di Polres Pematangsiantar
}

\author{
Rury Cassa Pirera \\ Universitas Muhammadiyah Sumatera Utara \\ e-mail: rurycassa@gmail.com
}

\begin{abstract}
A problem of traffic accident and to an accident into a a result of the current social problem .Human sacrifices in this case it could be in a state of died, suffered severe injuries, minor injuries and can cause material loss and damage to the vehicles involved in .Public relations pematangsiantar through police accident unit in reducing an accident for riders with put advertising banners appeals addressed to the message of the banners that affected attitude the rider when read it.Research methods that were used method of qualitative descriptive .This research result indicates that persuasive communication public relations pematangsiantar police largely through advertising banners in reducing an accident for the rider been going very well. $n$ the use of banners required characteristic of banners as installment area banners, design banners, clarity editor and size of banner for attracted the interest of the rider within view and read banners persuasive so the message delivered with good to motorists who saw it.
\end{abstract}

Key Word: Persuasive communication, banners, public relations

\begin{abstract}
Abstrak
Masalah kecelakaan lalu lintas dan akibat terjadinya suatu kecelakaan menjadi suatu masalah sosial saat ini. Korban manusia dalam hal ini bisa berada dalam keadaan meninggal dunia, mengalami luka berat, luka ringan maupun dapat menyebabkan kerugian materi dan kerusakan pada kendaraan yang terlibat. Humas kepolisian Polres Pematangsiantar melalui Unit Laka Lantas dalam mengurangi kecelakaan bagi pengendara dengan memasang iklan spanduk imbauan agar pesan dalam spanduk tersebut mempengaruhi sikap pengendara ketika membacanya. Metode penelitian yang digunakan metode deskriptif kualitatif. Hasil penelitian ini menunjukkan bahwa komunikasi persuasif humas Kepolisian Polres Pematangsiantar melalui iklan spanduk dalam mengurangi kecelakaan bagi pengendara sudah berjalan dengan baik. Dalam menggunakan spanduk diperlukan karakteristik spanduk seperti lokasi pemasangan spanduk, desain spanduk, kejelasan redaksi dan ukuran spanduk untuk menarik minat pengendara dalam melihat dan membaca spanduk sehingga pesan persuasif tersampaikan dengan baik kepada pengendara yang melihatnya.
\end{abstract}

Kata kunci : Komunikasi Persuasif, Humas, Spanduk. 
Latar Belakang Masalah

Kebutuhan komunikasi pada saat ini sangat penting dalam kehidupan manusia. Jika dilihat manusia merupakan makhluk sosial yang saling membutuhkan satu sama lain, manusia tidak akan bisa hidup tanpa adanya komunikasi yang terjalin diantara mereka. Komunikasi yang terjalin tersebut akan efektif bila menimbulkan pengaruh pada sikap seseorang. Upaya komunikasi untuk mempengaruhi sikap seseorang ini disebut sebagai komunikasi persuasif. Sasaran komunikasi ketika menerima pesan komunikasi/message tidak merasakan adanya perubahan sikap atau pendapat bahkan juga tingkah lakunya. Karena perubahan yang terjadi itu cenderung dirasakan oleh pihak komunikan seolah-olah datang atas kehendaknya sendiri, dan ia tidak merasa adanya unsur paksaan ketika menerima pesan komunikasi tersebut.

Bagi kegiatan humas, komunikasi persuasif sangat dibutuhkan untuk mengubah kepercayaan, sikap dan prilaku masyarakat. Menurut Littlejohn (Ritonga, 2006), pesan persuasif dipandang sebagai usaha sadar untuk mengubah pikiran dan tindakan dengan memanipulasi motif-motif ke arah tujuan yang telah ditetapkan. Makna memanipulasi bukanlah mengurangi atau menambah fakta sesuai konteksnya, tetapi dalam memanfaatkan faktum-faktum yang berkaitan dengan motif khalayak sasaran, sehingga tergerak untuk mengikuti maksud pesan yang telah disampaikan.

Dalam komunikasi persuasif terdapat komponen atau elemen sehingga dapat disebut sebagai komunikasi persuasif. Komponen tersebut antaranya: a) Claim, yaitu pernyataan tujuan persuasif baik yang tersurat (eksplisit) maupun tersirat (implisit). b) Warrant, yaitu perintah yang dibungkus dengan ajakan atau bujukan sehingga terkesan tidak memaksa. c) Data, yaitu data-data atau fakta-fakta yang digunakan untuk memperkuat argumentasi keunggulan pesan dari komunikator. (Maulana dan Gumelar, 2013)

Dalam pelaksanaannya, komunikasi persuasif lebih sering dilakukan oleh humas. Humas dalam definisi luas adalah bentuk 
komunikasi persuasif dan terencana yang ditujukan untuk mempengaruhi publik yang berarti. Artinya humas bukan hanya dilakukan saat dibutuhkan saja, karena dalam hal ini satu pihak menginginkan pihak lain untuk melakukan atau mempercayai sesuatu dan itu dilakukan lewat komunikasi. Morissan (2008) menegaskan bahwa humas kemudian memasukkan kata-kata seperti reciprocal (timbal balik), mutual (saling) dan between (antara), dengan demikian, pengertian humas sudah mengandung pengertian aksi timbal balik (interaktif).

Sasaran humas dalam kegiatannya adalah publik, yaitu satu kelompok dalam masyarakat yang memiliki karakteristik kepentingan yang sama. Humas bertanggung jawab untuk memberikan informasi, mendidik, meyakinkan, meraih simpati, dan membangkitkan ketertarikan publik akan sesuatu atau membuat mengerti dan menerima sebuah situasi. Seorang humas dalam mempengaruhi publik melalui penyajian pesan komunikasi yang disampaikannya tidak boleh dilakukan secara paksaan. Jika mempengaruhi publik, penyajian pesan komunikasi itu harus dapat menumbuhkan kesadaran dalam diri sehingga kegiatan yang dilakukan timbul berdasarkan kemauan, bukan akibat dari penerimaan pesan komunikasi tersebut.

Humas dan periklanan memiliki hubungan yang sangat erat. Iklan atau advertising menurut Morissan (2010) dapat didefinisikan sebagai setiap bentuk komunikasi nonpersonal mengenai suatu organisasi, produk, servis, atau ide yang dibayar oleh satu sponsor yang diketahui. Perusahaan atau organisasi hampir rata-rata menggunakan berbagai jenis iklan untuk mempengaruhi prilaku publik agar tercapai pesan yang ingin disampaikan. Namun iklan dipandang tidak lebih dari sekedar promosi jasa atau produk yang diperkenalkan melalui media. Secara umum, iklan berwujud penyajian informasi nonpersonal tentang suatu produk, merek, perusahaan, atau toko yang dijalankan dengan kompensasi biaya tertentu. Maka dari itu, iklan berupa proses komunikasi yang memiliki tujuan membujuk atau menarik orang banyak untuk mengambil tindakan yang 
menguntungkan pihak yang
membuat iklan.
Iklan layanan masyarakat

(ILM) merupakan iklan yang bertujuan untuk membela kepentingan publik, tidak komersil, membangkitkan kesadaran publik secara persuasi. Menurut Persatuan Perusahaan Periklanan Indonesia (PPPI), ILM adalah pesan komunikasi pemasaran untuk kepentingan publik tentang gagasan atau wacana untuk mengubah, memperbaiki atau meningkatkan sikap atau perilaku mereka. Produksi maupun penyiaran media ini sebagian atau seluruhnya dikelola dan atau didanai oleh pelaku periklanan. Sementara itu Philip Lesty (Danandjaja: 2011) menjelaskan "iklan layanan masyarakat" atau istilah pentingnya "Public Service Announcements" disingkat ILM atau PSA, menyebutkan kegiatan kampanye tentang informasi publik bersumber dari lembaga non profit (charitable organizations).

.ILM dapat dimanfaatkan untuk membantu memperbaiki perilaku atau kebiasaan masyarakat yang tidak sesuai dengan hukum atau norma yang berlaku. Pesan sosial yang disampaikan melalui ILM diharapkan dapat meningkatkan kesadaran masyarakat dan mengubah perilaku ke arah perilaku yang baik dan kondisi lingkungan sosial yang kondusif.

Masalah kecelakaan lalu lintas dan fatalitas akibat terjadinya suatu kecelakaan menjadi suatu masalah sosial saat ini. Korban manusia dalam hal ini bisa berada dalam keadaan meninggal dunia, mengalami luka berat, luka ringan maupun dapat menyebabkan kerugian materi dan kerusakan pada kendaraan yang terlibat. Tingkat fatalitas suatu kecelakaan lalu lintas diukur dari akibat dari kecelakaan yang ada tersebut. semakin banyak korban meninggal dunia yang diakibatkan dari kecelakaan yang terjadi semakin tinggi pula fatalitas kecelakaan lalu lintas tersebut.

Kecelakan lalu lintas dapat terjadi karena disebabkan beberapa faktor yakni Faktor manusia, Faktor tersebut sebabkan oleh korban dalam hal kurang hati-hati pada waktu menggunakan jalan, menyeberang dan mengabaikan lampu pengatur pejalan kaki untuk menyeberang. 
Faktor manusia juga dapat menyebabkan kecelakaan lalu lintas karena kondisi pihak pengemudi itu antara lain kondisi kesehatan yang kurang baik, ngantuk, mabuk, minum alkohol/obat, serta penglihatan/pendengaran yang kurang baik.

Faktor kendaraan, antara lain perlengkapan yang tidak memadai berupa alat-alat rem tidak baik bekerja, alat-alat kemudi tidak baik kerjanya, serta ban/roda kondisi kurang baik penerangan yang kurang memadai serta pelanggaran tentang pemasangan jenis lampu penerangan juga merupakan dapat merupakan faktor penyebab terjadinya kecelakaan lalu lintas.

Dengan adanya permasalahan kecelakaan lalu lintas yang ada serta fatalitas dari tiap kecelakaan yang terjadi, kepolisian harus mengambil suatu tindakan dalam menjalankan tugas, fungsi dan perananannya dalam memberikan pelayanan kepada masyarakat. Maka humas kepolisian harus lebih kreatif dan cerdas dalam menghimbau masyarakat untuk mematuhi tertib berlalu lintas.
Humas Polri adalah jembatan penting yang menghubungkan media dengan polisi. Dalam rangka memberikan pelayanan publik, Kepolisian Negara Republik Indonesia melalui fungsi hubungan masyarakat, memerlukan standar pengolahan guna menjamin pelayanan informasi publik. Bidang humas adalah merupakan unsur pelaksanaan staf khusus yang bertugas menyelenggarakan fungsi kehumasan melalui penyampaian berita/informasi serta kerja sama dengan media dalam mengubah pola pikir masyarakat yang positif bagi pelaksanaan tugas Polri.

$$
\begin{aligned}
& \text { Humas kepolisian bekerja } \\
& \text { sama dengan bagian Unit Laka } \\
& \text { Lantas melakukan imbauan tertib } \\
& \text { berlalu lintas untuk mengurangi } \\
& \text { kecelakaan dan menyadarkan } \\
& \text { masyarakat yang berkendara yaitu } \\
& \text { salah satunya dengan memanfaatkan } \\
& \text { media iklan layanan masyarakat } \\
& \text { (ILM) sebagai cara memberikan } \\
& \text { imbauan kepada masyarakat agar } \\
& \text { mematuhi tata tertib berlalu lintas. } \\
& \text { Iklan Layanan Masyarakat (ILM) } \\
& \text { saat ini sangat banyak dan bervariasi } \\
& \text { jenisnya. Yaitu iklan imbauan yang } \\
& \text { ditayangkan di televisi dan juga }
\end{aligned}
$$


menggunakan spanduk dan famplet dipasang di persimpangan lampu merah, jalan protokol, maupun di persimpangan jalan.

\section{Metode Penelitian}

Jenis penelitian yang dipergunakan dalam penelitian ini adalah jenis kualitatif dengan sifat deskriptif. Metode penelitian deskriptif kualitatif dimaksudkan untuk eksplorasi dan klarifikasi mengenai suatu fenomena atau kenyataan sosial, dengan jalan mendeskripsikan sejumlah variabel yang berkenaan dengan masalah dan unit yang diteliti. Usaha untuk mendeskripsikan fakta-fakta pada tahap permulaan tertuju pada usaha mengemukakan gejala secara lengkap dalam aspek yang diselidiki agar jelas keadaan ataupun kondisinya. (Ardial: 2014)

\section{Hasil Penelitian dan Pembahasan}

$$
\text { Kepolisian }
$$

Polres

Pematangsiantar mempunyai kegiatan yang sifatnya pemberitahuan secara langsung kepada masyarakat khususnya bagi pengendara yaitu menggunakan iklan spanduk. Penggunaan iklan spanduk oleh pihak kepolisian merupakan salah satu cara mengurangi kecelakaan bagi pengendara. Spanduk ini adalah imbauan secara langsung kepada pengendara ketika pengendara melewati jalan yang dianggap rawan. selain itu spanduk adalah imbauan yang mudah dibaca dan cepat diingat dengan harapan apabila sering melewati dan melihat spanduk tersebut pengendara akan menaati dan mematuhi imbauan tersebut. Faktor yang memicu terjadinya kecelakaan namun yang paling sering adalah faktor pelanggaran dan kelalaian pengendara. Tidak pedulinya pengendara dalam menaati dan membaca rambu-rambu lalu lintas dapat memicu terjadinya kecelakaan.

Sesuai dengan apa yang dikemukakan oleh Effendy (2007) tentang fungsi komunikasi, ditemukan bahwa 4 fungsi tersebut berupaya untuk dapat dilakukan oleh humas kepolisian pematangsiantar dalam mengurangi resiko kecelakaan. Fungsi tersbut yakni: 1) Menyampaikan pesan, Humas Kepolisian Polres Pematangsiantar dalam menyampaikan informasi kepada pengendara dalam upaya 
mengurangi tingkat kecelakaan lalu lintas yaitu dengan menggunakan iklan spanduk, media sosial, koran dan baliho. 2) Mendidik, Metode mendidik pengendara agar mematuhi lalu lintas humas Kepolisian Polres Pematangsiantar melakukan kegiatan razia kelengkapan surat dan kelengkapan dalam berkendara. Kegiatan tersebut dilakukan agar mendidik pengendara untuk lebih mematuhi peraturan rambu-rambu lalu lintas dan menghindari kecelakaan dan keselamatan pengendara. 3) Menghibur, Humas Kepolisian Polres Pematangsiantar menggunakan gambar yang unik dan menarik dalam iklan spanduk imbauan yang bertujuan selain untuk menghibur juga sebagai cara agar pesan yang terdapat dalam iklan spanduk imbauan tersebut tersampaikan dengan baik. 4) Komunikasi sebagai sarana, Komunikasi sebagai sarana adalah untuk mempengaruhi khalayak dalam memperkenalkan nilai-nilai baru untuk mengubah sikap dan prilaku ke arah yang lebih baik. Humas kepolisian menggunakan iklan spanduk dalam menyampaikan pesan kepada pengendara agar mengubah sikap dan prilaku pengendara untuk lebih hati-hati dan mematuhi rambu-rambu lalu lintas.

Sementara itu terkait dengan tindakan komunikasi persuasif yang dilakukan oleh humas polres Pematangsiantar, pihak humas polres Pematangsiantar telah melakukan hal tersebut yakni melalui pendataan daerah yang rawan terjadi kecelakaan. Tindakan tersebut dilakukan agar spanduk atau pesan yang akan dipajang memiliki nilai lebih sehingga tidak salah dalam pemasangan spanduk pesan yang berisi tentang keselamatan berlalu lintas.

Selain melakukan pendataan daerah rawan kecelakaan, pihak humas polres Pematangsiantar dalam menyajikan pesan yang termuat di spanduk juga menggunakan katakata yang bersifat tegas, singkat, simple dan mudah untuk diingat serta dipahami, sehingga harapannya pesan yang disampaikan akan ditaati dan dipatuhi oleh pengendara yang melintas.

Humas kepolisian Polres Pematangsiantar dalam menggunakan media iklan spanduk untuk mengurangi kecelakaan bagi 


$\begin{aligned} & \text { pengendara tetap senantiasa } \\ & \text { memperhatikan } \\ & \text { karakteristik }\end{aligned}$
spanduk seperti lokasi pemasangan
spanduk, desain spanduk, ukuran
huruf dan ukuran spanduk untuk
menarik minat pengendara dalam
melihat dan membaca spanduk
tersebut.

Berdasarkan hasil penelitian yang dilakukan pemasangan spanduk sangat mempengaruhi pengendara dalam melihat dan membaca spanduk tersebut. Dalam sebuah spanduk imbauan berlalu lintas akan sangat menarik dibaca apabila penempatannya dapat terlihat jelas oleh pengendara. Pemilihan posisi penempatan yang baik pada spanduk terlihat dari bagaimana pengendara dapat melihat dengan jelas tanpa tertutupi benda-benda disekitar spanduk.

Dalam sebuah spanduk akan sangat mudah diingat spanduk jika isi pesan spanduk memiliki desain warna yang mencolok sehingga menarik pengendara untuk membaca serta melaksanakan apa yang telah dihimbaukan dengan sadar tanpa adanya tekanan. Informasi yang terdapat pada spanduk tersebut dapat diikuti atau tidaknya tergantung kepada pengendara, namun bagi masyarakat yang mengendarai kendaraan diperlukan desain warna yang mencolok maupun gambar yang unik sangat penting agar pesan dapat tersampaikan dengan baik. Pihak humas kepolisian Pematangsiantar dalam penggunaan spanduk imbauan menggunakan desain dengan latar belakang yang berwarna kuning dan warna huruf yang berwarna merah. Adapun gambar yang dibuat tergantung dengan isi pesan yang terdapat di dalam spanduk tersebut. Meskipun faktanya dilapangan masih terdapat spanduk yang masih kurang jelas untuk dibaca karena ukuran huruf yang terlalu kecil dan warna spanduk yang sudah pudar.

Selain lokasi pemasangan spanduk dan desain warna dalam menarik minat masyarakat, pihak Humas Kepolisian Polres Pematangsiantar menentukan ukuran dalam pemasangan spanduk imbauan. Ukuran spanduk yang dibuat pihak Kepolisian Polres Pematangsiantar panjangnya 5 meter dan lebar 1 meter. Adapun spanduk yang lebih besar dari itu dengan kebutuhan gambar yang sesuai 
dengan isi pesan tersebut. Hal ini

dilakukan guna mempermudah pengendara untuk dapat membaca pesan yang dimaksud tanpa mengganggu konsentrasinya dalam membawa kendaraan.

\section{Penutup}

Komunikasi persuasif humas kepolisian Polres Pematangsiantar melalui iklan spanduk dalam mengurangi kecelakaan bagi pengendara sudah cukup baik dan membuat pengendara lebih sadar dalam berkendara serta menaati rambu lalu lintas. Dalam menyampaikan pesan terkait dengan himbauan untuk berhati-hati di dalam perjalanan, humas polres Pematangsiantar menggunakan berbagai media antara lain surat kabar, majalah, spanduk dan baliho.

Pengunaan spanduk sebagai media dalam menyampaikan pesan bagi pengendara dilakukan dengan tetap memperhatikan lokasi pemasangan spanduk, desain spanduk, ukuran huruf dan ukuran spanduk dengan tujuan agar pengendara mudah membaca dan memahami pesan yang disampaikan.

\section{Daftar Pustaka}

Ardial(ed). 2014. Paradigma dan Model Penelitian Komunikasi. Jakarta: PT. Bumi Aksara.

Danandjaja. 2011. Peranan Humas Dalam Perusahaan. Yogyakarta: Graha Ilmu.

Effendy, Onong Uchana. 2007. Ilmu Komunikasi Teori dan Praktek. Bandung: Remaja Rosdakarya.

Maulana, Herdiyan dan Gumgum Gumelar. 2013. Psikologi Komunikasi dan Persuasi. Jakarta: Akademia Permata.

Morissan. 2010. Periklanan Komunikasi Pemasaran Tepadu. Jakarta: Kencana.

Morissan. 2008. Manajemen Public Relations. Jakarta: Kencana.

Ritonga, M. Jamiluddin. 2006. Tipologi Pesan Persuasif. Jakarta: Indeks. 